\title{
Radiological impact of phosphogypsum surface application in a no-till system in Southern Brazil
}

\author{
Nivea Maria Piccolomini Dias( ${ }^{(1)}$, Eduardo Fávero Caires ${ }^{(2)}$, Luiz Fernando Pires ${ }^{(1)}$, Márcio Arruda Bacchi( ${ }^{(3)}$ \\ and Elisabete Aparecida de Nadai Fernandes ${ }^{(3)}$
}

\begin{abstract}
(1)Universidade Estadual de Ponta Grossa (UEPG), Laboratório de Física Aplicada a Solos e Ciências Ambientais, CEP $84030-900$ Ponta Grossa, PR, Brazil. E-mail: diasnmp@gmail.com, Ifpires@uepg.br (2)UEPG, Departamento de Ciência do Solo e Engenharia Agrícola. E-mail: efcaires@uepg.br (3)Universidade de São Paulo, Centro de Energia Nuclear na Agricultura, Laboratório de Radioisótopos, Caixa Postal 96, CEP 13400-970 Piracicaba, SP, Brazil. E-mail: mabacchi@cena.usp.br, lis@cena.usp.br
\end{abstract}

\begin{abstract}
The objective of this work was to determine the impact of phosphogypsum application on ${ }^{226} \mathrm{Ra}$ and ${ }^{228} \mathrm{Ra}$ activities in the soil and on their accumulation in soybean grains. A field experiment was carried out in Paraná state, Brazil, on a loamy Typic Hapludox, under no-till system, with increasing phosphogypsum rates: 4, 8, and $12 \mathrm{Mg} \mathrm{ha}^{-1}$. Gamma-ray spectrometry was carried out using HPGe detectors with 45 and $10 \%$ relative efficiencies, for soybean grains and soil, respectively. No increment of ${ }^{226} \mathrm{Ra}$ and ${ }^{228} \mathrm{Ra}$ activities was observed due to the increase in phosphogypsum rates in the soil, and a small reduction was noticed in the grains. Average values found for ${ }^{226} \mathrm{Ra}$ and ${ }^{228} \mathrm{Ra}$ activities were 37 and $57 \mathrm{~Bq} \mathrm{~kg}^{-1}$ in the soil and 1.44 and $3.19 \mathrm{~Bq} \mathrm{~kg}^{-1}$ in soybean grains. The application of phosphogypsum for no-till soybean production is a safe practice regarding the risks of radiation damage to human health.
\end{abstract}

Index terms: Glycine max, gamma spectrometry, radioactivity, ${ }^{226} \mathrm{Ra},{ }^{228} \mathrm{Ra}$.

\section{Impacto radiológico da aplicação superficial de gesso agrícola em sistema de plantio direto no Sul do Brasil}

\begin{abstract}
Resumo - O objetivo deste trabalho foi determinar o impacto da aplicação superficial de gesso agrícola sobre as atividades de ${ }^{226} \mathrm{Ra}$ e ${ }^{228} \mathrm{Ra}$ no solo e sobre seu acúmulo nos grãos de soja. Foi realizado um experimento de campo no Estado do Paraná, Brasil, em um Latossolo Vermelho de textura média, sob sistema de plantio direto, com doses crescentes de gesso agrícola: 4,8 e $12 \mathrm{Mg} \mathrm{ha}^{-1}$. A espectrometria de raios gama foi realizada com uso de detectores de HPGe, com eficiência relativa de 45 e $10 \%$, para os grãos de soja e para o solo, respectivamente. Nenhum incremento nas atividades de ${ }^{226} \mathrm{Ra} \mathrm{e}^{228} \mathrm{Ra}$ foi verificado no solo em razão do aumento das doses de gesso agrícola, e uma pequena redução foi observada nos grãos. Os valores médios de atividade encontrados para o ${ }^{226} \mathrm{Ra}$ e ${ }^{228} \mathrm{Ra}$ foram 37 e $57 \mathrm{~Bq} \mathrm{~kg}^{-1}$ no solo e 1,44 and $3,19 \mathrm{~Bq} \mathrm{~kg}^{-1}$ nos grãos de soja. A aplicação de gesso agrícola na soja produzida em plantio direto é uma prática segura quanto aos riscos de exposição e danos da radiação para a saúde humana.
\end{abstract}

Termos para indexação: Glycine max, espectrometria gama, radioatividade, ${ }^{226} \mathrm{Ra},{ }^{228} \mathrm{Ra}$.

\section{Introduction}

Phosphogypsum (PG) is a by-product of the phosphate fertilizer industry that contains mainly calcium sulfate $\left(\mathrm{CaSO}_{4} \cdot 2 \mathrm{H}_{2} \mathrm{O}\right)$ and small concentrations of phosphorous and fluorine. The huge demand for phosphate fertilizer with high $\mathrm{P}$ content in agriculture has led to a global production of about 170 million megagrams of PG per year (Abril et al., 2008). Surface-applied PG followed by its leaching to acidic subsoils results in improvement of root growth and higher absorption of water and nutrients by plant roots as a result of the increase in calcium content, the formation of less toxic aluminum species $\left(\mathrm{AlSO}_{4}^{+}\right)$and precipitation of $\mathrm{Al}^{3+}$ (Shainberg et al., 1989; Carvalho \& Raij, 1997; Caires et al., 2003). Thus, PG has been largely used in agriculture in order to improve subsoil fertility.

No-till systems with diversified crop rotations have stood out as one of the most effective strategies to improve the sustainability of farming in tropical and subtropical regions, contributing to minimize soil and nutrient losses by erosion. No-till has shown a rapid increase in area in Brazil, currently taking up some 26 million hectares, and soybean is the most commonly cultivated crop. To control soil acidity in established no-till systems, lime is spread on the surface without incorporation. Because surface lime application in

Pesq. agropec. bras., Brasília, v.45, n.12, p.1456-1464, dez. 2010 
general does not reduce soil acidity far beyond the point of placement (Ernani et al., 2004; Caires et al., 2005), the use of $P G$ has been an effective practice to improve the chemical conditions in the subsoil under no-till farming (Caires et al., 1998, 2003).

Phosphogypsum has radionuclides from uranium $\left({ }^{238} \mathrm{U}\right)$ and thorium $\left({ }^{232} \mathrm{Th}\right)$ series in its composition, due to their occurrence in the phosphate rocks (Silva, 2001). Amongst such radionuclides, ${ }^{226} \mathrm{Ra}$, from ${ }^{238} \mathrm{U}$ series, and ${ }^{228} \mathrm{Ra}$, from ${ }^{232} \mathrm{Th}$ series, are the most important sources of radioactivity in PG (Rutherford et al., 1994). ${ }^{226} \mathrm{Ra}$ is characterized by long half-lifetime ( $\mathrm{T}=1,602$ years), the emission of $\alpha$ particles and by low-energy gamma-rays. ${ }^{228} \mathrm{Ra}$ has the half-lifetime of 5.75 years and the emission of $\beta$ particles. Both Ra elements have a biological behavior similar to $\mathrm{Ca}$ deposited in mammal bones (Choppin \& Rydberg, 1980)

The presence of radionuclides has generated discussions on the impact of PG on human health (Ettenhuber \& Lehmann, 1986), and its use in agriculture is restricted by certain countries. In the USA, the maximum limit of ${ }^{226} \mathrm{Ra}$ in $\mathrm{PG}$ was set as $370 \mathrm{~Bq} \mathrm{~kg}{ }^{-1}$ (United States Environmental Protection Agency, 1998). In Brazil, Mazzilli et al. (2000) registered activities ranging from 10 to $1,200 \mathrm{~Bq} \mathrm{~kg}^{-1}$ for radionuclides from ${ }^{238} \mathrm{U}$ and ${ }^{232} \mathrm{Th}$ series in the phosphate rocks used in the fertilizer industry. Also, ${ }^{226} \mathrm{Ra}$ and ${ }^{228} \mathrm{Ra}$ contents were measured in the Brazilian PG produced from different phosphate fertilizer industries; Saueia et al. (2005) obtained activities for ${ }^{226} \mathrm{Ra}$ and ${ }^{228} \mathrm{Ra}$ that varied from 24 to $700 \mathrm{~Bq} \mathrm{~kg}{ }^{-1}$ and 29 to $273 \mathrm{~Bq} \mathrm{~kg}^{-1}$, respectively, and Santos et al. (2006) from 214 to $247 \mathrm{~Bq} \mathrm{~kg}^{-1}$ for ${ }^{226} \mathrm{Ra}$ and 350 to $811 \mathrm{~Bq} \mathrm{~kg}^{-1}$, for ${ }^{228} \mathrm{Ra}$. Parreira et al. (2001) showed that ${ }^{228} \mathrm{Ac},{ }^{208} \mathrm{Ti},{ }^{212} \mathrm{Bi}$ (from ${ }^{232} \mathrm{Th}$ series), ${ }^{214} \mathrm{~Pb}$ and ${ }^{214} \mathrm{Bi}$ (from ${ }^{238} \mathrm{U}$ series) and ${ }^{40} \mathrm{~K}$ were transferred from the $\mathrm{PG}$ to the soil.

Despite the various studies found in the literature on the use of PG in agriculture (Hull \& Burnett, 1996; Burnett \& Elzerman, 2001; Beddow et al., 2006; Papastefanou et al., 2006; Abril et al., 2008, 2009), there are only few studies on the presence of radionuclides in PG produced in Brazil (Silva, 2001; Silva et al., 2001; Saueia et al., 2005; Santos et al., 2006; Jacomino et al., 2009). Moreover, there is very little information available on the addition of radionuclides through PG application in Brazilian agriculture (Parreira et al.,
2001; Dias et al., 2010), mainly in the regions where the no-till farming predominates, as the South of Brazil.

Considering that the use of PG might result in increased amounts of radionuclides in the soil-plant system, and a consequent threat to human health, studies that can provide data aiming at the regulation of PG use in agriculture are essential.

The objective of this work was to determine the impact of phosphogypsum (PG) application on ${ }^{226} \mathrm{Ra}$ and ${ }^{228} \mathrm{Ra}$ activities in the soil and on their accumulation in soybean grains.

\section{Materials and Methods}

The experiment was performed in Ponta Grossa, Paraná state, Brazil $\left(25^{\circ} 05^{\prime} 58^{\prime \prime} \mathrm{S}\right.$ and $\left.59^{\circ} 09^{\prime} 30^{\prime \prime} \mathrm{W}\right)$, on a loamy Typic Hapludox. Topsoil $(0-0.2 \mathrm{~m})$ had the following characteristics: $\mathrm{Ca}^{2+}, 16 \mathrm{mmol}_{\mathrm{c}} \mathrm{dm}^{-3} ; \mathrm{P}$ (Mehlich-1), $9.0 \mathrm{mg} \mathrm{dm}^{-3}$, total organic matter, $33 \mathrm{~g}$ $\mathrm{dm}^{-3}$; and 295, 240, and $465 \mathrm{~g} \mathrm{~kg}^{-1}$ of clay, silt and sand, respectively. The clay fraction had $265.8 \mathrm{~g} \mathrm{~kg}^{-1}$ of kaolinite (90.1\%), $26.8 \mathrm{~g} \mathrm{~kg}^{-1}$ of goethite $(9.1 \%)$, and $2.4 \mathrm{~g} \mathrm{~kg}^{-1}$ of hematite $(0.8 \%)$. The experimental site had been used for grain cropping under no-till system for 15 years before the establishment of the experiment.

A randomized complete block design was used, with three replicates. Treatments were applied to plots of $50.4 \mathrm{~m}^{2}(8.0 \times 6.3 \mathrm{~m})$, with four different rates of PG: $0,4,8$, and $12 \mathrm{Mg} \mathrm{ha}^{-1}$ on the soil surface. PG, coming from Cajati county (São Paulo state), had $235 \mathrm{~g} \mathrm{~kg}^{-1}$ $\mathrm{Ca}, 153 \mathrm{~g} \mathrm{~kg}^{-1} \mathrm{~S}, 3 \mathrm{~g} \mathrm{~kg}^{-1} \mathrm{P}$, and $156 \mathrm{~g} \mathrm{~kg}^{-1}$ water. ${ }^{226} \mathrm{Ra}$ and ${ }^{228} \mathrm{Ra}$ activity concentrations in PG were 47.5 and 43.3 $\mathrm{Bq} \mathrm{kg}^{-1}$, respectively.

Soybean (Glycine $\max$ L. Merril) was cultivated during the spring-summer season, and cereal crops during the autumn-winter season. Fertilizer rates varied with crops and years, according to soil test recommendations for the Paraná state. Nitrogen, P, and $\mathrm{K}$ were applied as urea, triple superphosphate, and potassium chloride, respectively. Plant residues were left on the soil surface following grain harvest. More details about the cropping history and fertilization are reported by Caires et al. (2005).

Soil samples were taken after soybean (cv. CD 214 RR) harvest in 2007. In order to obtain a composite sample, 12 soil cores at $0-0.2 \mathrm{~m}$ depth, and five soil cores at $0.2-0.4,0.4-0.6$, and $0.6-0.8 \mathrm{~m}$ depth were collected from each plot using a hand probe. Samples 
were oven-dried at $60^{\circ} \mathrm{C}$ for 24 hours, manually ground and sieved (1 mm mesh). Then, they were placed in $150 \mathrm{~mL}$ cylindrical containers and sealed. Soybean was harvested from a $12 \mathrm{~m}^{2}$ plot. Grains were washed with running freshwater dried at $60^{\circ} \mathrm{C}$ and sealed in 2 L Marinelli containers. After sealed all samples were stored for a 3-week minimum period, in order to ensure the radioactive equilibrium amongst ${ }^{226} \mathrm{Ra}$ and its short-lived daughters $\left({ }^{214} \mathrm{~Pb}\right.$ and $\left.{ }^{214} \mathrm{Bi}\right)$.

Determinations of radionuclides were carried out at the Radioisotopes Laboratory of the Centro de Energia Nuclear na Agricultura (Cena/USP), in Piracicaba, São Paulo state, Brazil. Two hyperpure-Ge detectors were used: Ortec model GEM10195 (for soil) and GEM45190 (for grains), with 10 and 45\% relative efficiencies and 1.85 and $1.95 \mathrm{keV}$ resolutions for the photopeak $1,332 \mathrm{keV}$ of ${ }^{60} \mathrm{Co}$, both coupled to a Ortec 919E multichannel analyzer. Soil samples remained in the spectrometer for 12 hours, while soybean samples were measured for 24 hours, since they showed lower activity. Background radiation was evaluated in both detectors during 48 hours, using the same experimental setup and replacing samples by deionized water. For acquisition and spectral analysis, the programs Gamma Vision by Ortec and Quantu, developed in the Cena's Radioisotopes Laboratory, were employed.

The activity of ${ }^{226} \mathrm{Ra}$ in the soil and grains was determined by averaging results from the 295 and $352 \mathrm{keV}$ photopeaks of ${ }^{214} \mathrm{~Pb}$, and $609 \mathrm{keV}$ photopeak of ${ }^{214} \mathrm{Bi}$. ${ }^{228} \mathrm{Ra}$ was determined from the gamma ray lines: $239 \mathrm{keV}$ of ${ }^{212} \mathrm{~Pb}$; 338, 911, and $969 \mathrm{keV}$ of ${ }^{228} \mathrm{Ac}$ for soil; and 338, 911 and $969 \mathrm{keV}$ of ${ }^{228} \mathrm{Ac}$ for grains. ${ }^{212} \mathrm{~Pb}$ was not used for grains due to the lack of radioactive equilibrium between ${ }^{228} \mathrm{Ra}$ and ${ }^{228} \mathrm{Th}$. Count rates were transformed to activities by using the detection efficiency, calculated by an in-house software based on a semiempirical calibration approach adapted from the literature (Bacchi et al., 2000). The quality of results were checked by analysis of certified reference materials produced by the International Atomic Energy Agency, i.e. Soil 6, IAEA-326, IAEA-327 and IAEA-368. In grains, the minimum detectable activity for ${ }^{226} \mathrm{Ra}$ was $0.36 \mathrm{~Bq} \mathrm{~kg}^{-1}$ and for ${ }^{228} \mathrm{Ra}$ it was $0.55 \mathrm{~Bq} \mathrm{~kg}^{-1}$, while the minimum detectable activities in the soil were $6 \mathrm{~Bq} \mathrm{~kg}^{-1}$ and $13 \mathrm{~Bq} \mathrm{~kg}^{-1}$ for ${ }^{226} \mathrm{Ra}$ and ${ }^{228} \mathrm{Ra}$. The count rates obtained for soil samples were at least 20 times higher than the measured background for both ${ }^{226} \mathrm{Ra}$ and
${ }^{228} \mathrm{Ra}$, while for grain samples the values found were, in average, 4 and 8-fold higher than the background, respectively for ${ }^{226} \mathrm{Ra}$ and ${ }^{228} \mathrm{Ra}$.

The soil-plant transfer factor (TF) was calculated as: $\mathrm{TF}=\mathrm{A}_{\text {plant }} / \mathrm{A}_{\text {soil }}$, in which $\mathrm{A}\left(\mathrm{Bq} \mathrm{kg}{ }^{-1}\right)$ represents the activity concentrations in grains and in the soil (Papastefanou et al., 2006).

The potential radiological impact from soybean ingestion was assessed through the effective dose $\left(\mathrm{D}_{\mathrm{e}}, \mathrm{Sv} \mathrm{y}^{-1}\right): \mathrm{D}_{\mathrm{e}}=\mathrm{e}(\mathrm{g}) \times \mathrm{A} \times \mathrm{T}$, in which $\mathrm{e}(\mathrm{g})\left(\mathrm{Sv} \mathrm{Bq}{ }^{-1}\right)$ represents the effective dose coefficient and $\mathrm{T}$ (kg per year) is the soybean annual consumption rate (Papastefanou et al., 2006; Scheibel, 2006).

Data from soybean grain were evaluated by analysis of variance using a randomized complete block design in SAS software (SAS Institute, 1985). Data from soil were evaluated as a split plot design by analysis of variance using PG rates as main plots, and depths as subplots. The PG effects were compared by regression analyses, and the soil depths effects were compared by the Tukey test at $5 \%$ probability.

\section{Results and Discussion}

Activity concentrations of ${ }^{226} \mathrm{Ra}$ and ${ }^{228} \mathrm{Ra}$ in the soil were not significantly influenced by the interaction between PG rates and soil depth. Surface-applied PG did not significantly modified the concentrations of ${ }^{226} \mathrm{Ra}$ and ${ }^{228} \mathrm{Ra}$ in any of the four depths studied (Figure 1). Concentrations of ${ }^{226} \mathrm{Ra}$ varied from 33.8 to 38.4 $\mathrm{Bq} \mathrm{kg}^{-1}(0-0.2 \mathrm{~m}), 32.4$ to $37.9 \mathrm{~Bq} \mathrm{~kg}^{-1}(0.2-0.4 \mathrm{~m})$, 36.6 to $38.4 \mathrm{~Bq} \mathrm{~kg}^{-1}(0.4-0.6 \mathrm{~m})$, and 37.3 to 40.1 $\mathrm{Bq} \mathrm{kg}^{-1}$ (0.6-0.8 m); while ${ }^{228} \mathrm{Ra}$ varied from 51.1 to 55.7 $\mathrm{Bq} \mathrm{kg}^{-1}(0-0.2 \mathrm{~m}), 53.7$ to $56.0 \mathrm{~Bq} \mathrm{~kg}^{-1}(0.2-0.4 \mathrm{~m}), 56.0$ to $60.4 \mathrm{~Bq} \mathrm{~kg}^{-1}(0.4-0.6 \mathrm{~m})$, and 59.4 to $63.5 \mathrm{~Bq} \mathrm{~kg}^{-1}(0.6-$ $0.8 \mathrm{~m})$. It should be noticed that ${ }^{228} \mathrm{Ra}$ concentrations found in the soil were almost twice as much as ${ }^{226} \mathrm{Ra}$ concentrations, which might be due to the soil parent material and to the use of fertilizers or other agricultural inputs. Phosphate rocks, for instance, might be from sedimentary or igneous origin, the former showing higher concentrations of ${ }^{238} \mathrm{U}$, while the latter shows higher concentrations of ${ }^{232} \mathrm{Th}$. In Brazil, $80 \%$ of the phosphate rock used in the industry for phosphoric acid production comes from igneous origin (Canut, 2006). Therefore, there are higher ${ }^{232} \mathrm{Th}$ concentrations than ${ }^{238} \mathrm{U}$ and, consequently, higher ${ }^{228} \mathrm{Ra}$ concentrations than ${ }^{226} \mathrm{Ra}$. However, natural phosphates in the USA 
are from sedimentary origin (Albuquerque, 1996) and show higher ${ }^{238} \mathrm{U}$, thus higher ${ }^{226} \mathrm{Ra}$ content.

Concentrations of ${ }^{226} \mathrm{Ra}$ (average value $37 \mathrm{~Bq} \mathrm{~kg}^{-1}$ ) and ${ }^{228} \mathrm{Ra}$ (average value $57 \mathrm{~Bq} \mathrm{~kg}^{-1}$ ) found in the soil, after PG addition (Figure 1), are within the range cited in the literature for Brazilian soils. Malanca et al. (1993) assessed the activity concentration of ${ }^{226} \mathrm{Ra}$, in 51 soils of Rio Grande do Norte state, and observed values between 10 and $138 \mathrm{~Bq} \mathrm{~kg}^{-1}$. Jacomino et al. (2009) determined ${ }^{226} \mathrm{Ra}$ and ${ }^{228} \mathrm{Ra}$ in soils of Minas Gerais state, obtaining respectively 69 and $114 \mathrm{~Bq} \mathrm{~kg}^{-1}$ for a clay soil, and lower than 20 and $34 \mathrm{~Bq} \mathrm{~kg}^{-1}$ for a loam soil. Regarding the PG composition of the main industries producing phosphate fertilizers in Brazil, concentrations varied from 22 to $1,251 \mathrm{~Bq} \mathrm{~kg}^{-1}$ for ${ }^{226} \mathrm{Ra}$ and from 29 to $280 \mathrm{~Bq} \mathrm{~kg}^{-1}$ for ${ }^{228} \mathrm{Ra}$ (Mazzilli et al., 2000; Silva et al., 2001; Saueia et al., 2005; Santos et al., 2006).

In soils of other countries, effects of PG addition on the activity of ${ }^{226} \mathrm{Ra}$ were relatively similar to those observed in the present study. In agricultural areas in Greece, Papastefanou et al. (2006) found activity concentrations of ${ }^{226} \mathrm{Ra}$ varying from 37 to $54 \mathrm{~Bq} \mathrm{~kg}{ }^{-1}$ without $\mathrm{PG}$ addition, and 50 to $479.0 \mathrm{~Bq} \mathrm{~kg}^{-1}$ with $\mathrm{PG}$ addition to the soil. In Spain, concentrations of ${ }^{226} \mathrm{Ra}$ in the soil $(0-0.3 \mathrm{~m})$ were 35.3 and $39.3 \mathrm{~Bq} \mathrm{~kg}^{-1}$, respectively without and with PG application at $25 \mathrm{Mg} \mathrm{ha}^{-1}$, which
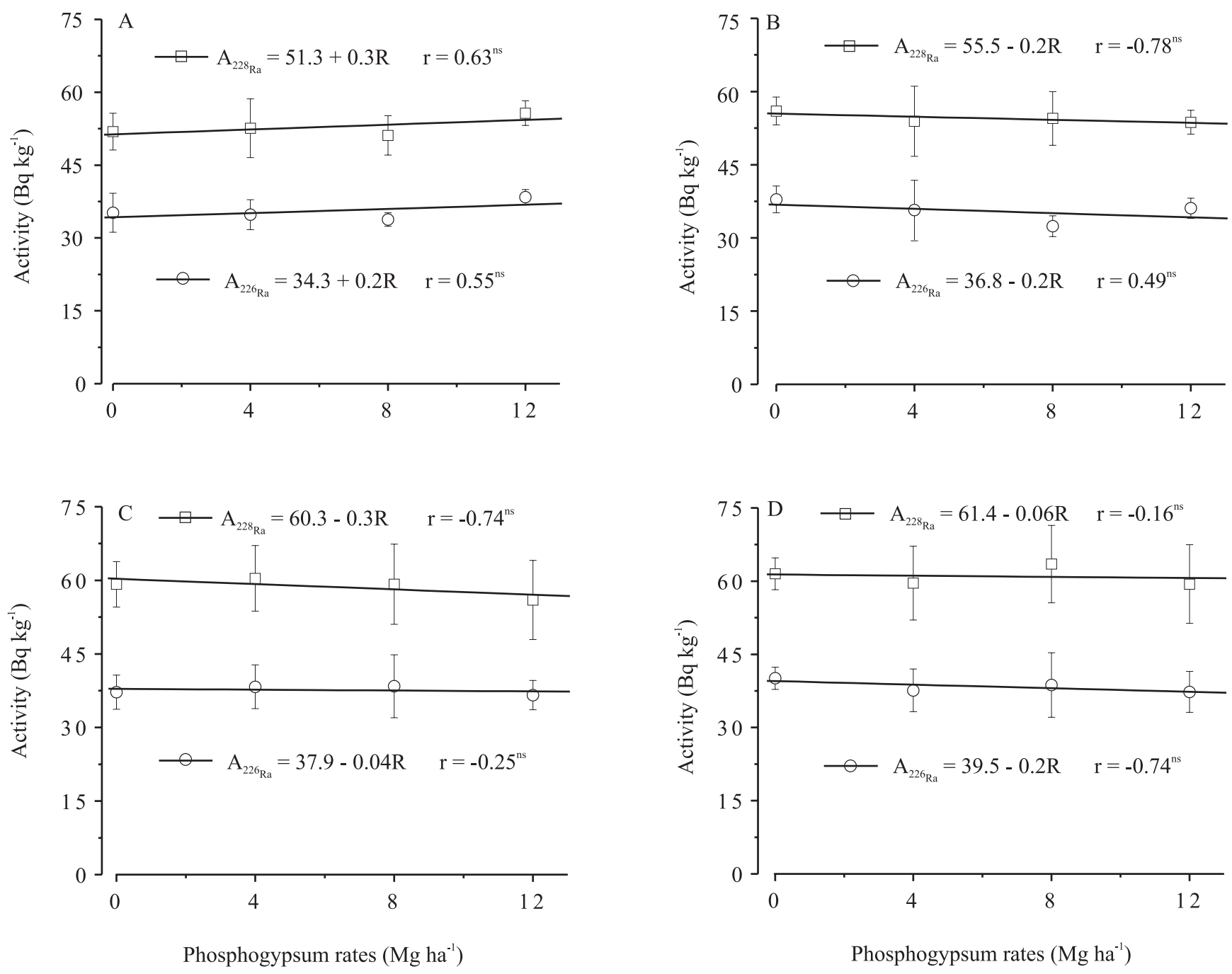

Figure 1. ${ }^{226} \mathrm{Ra}$ and ${ }^{228} \mathrm{Ra}$ activities at different soil depths, according to the applied phosphogypsum rates (R): A, 0-0.2 m; B, $0.2-0.4 \mathrm{~m} ; \mathrm{C}, 0.4-0.6$; D, 0.6-0.8 m. ${ }^{\mathrm{n}}$ Nonsignificant at 5\% probability. Error bars represent standard deviation $(\mathrm{n}=3)$. 
means no significant difference in the activity with the use of PG (Abril et al., 2008).

Regardless the rates of PG applied, an increase in the concentrations of ${ }^{226} \mathrm{Ra}$ and ${ }^{228} \mathrm{Ra}$ was noticed along soil depth. Considering the average rates of $\mathrm{PG},{ }^{226} \mathrm{Ra}$ and ${ }^{228} \mathrm{Ra}$ were significantly lower at $0-0.2 \mathrm{~m}$ (35.6 and $\left.52.8 \mathrm{~Bq} \mathrm{~kg}^{-1}\right)$ and $0.2-0.4 \mathrm{~m}\left(35.5\right.$ e $\left.54.5 \mathrm{~Bq} \mathrm{~kg}^{-1}\right)$ than at $0.4-0.6 \mathrm{~m}\left(37.6\right.$ and $\left.58.7 \mathrm{~Bq} \mathrm{~kg}^{-1}\right)$ and $0.6-0.8 \mathrm{~m}$ (38.5 and $61 \mathrm{~Bq} \mathrm{~kg}^{-1}$ ). Bacchi (1996) also observed an increase of ${ }^{226} \mathrm{Ra}$ and ${ }^{228} \mathrm{Ra}$ in deeper layers of Brazilian Oxisols. However, the opposite behavior was observed for temperate soils, in other countries (Bolca et al., 2007; Abril et al., 2008). In Turkey, Bolca et al. (2007) found concentrations of radionuclides positively correlated to the soil organic matter content $(r=0.93)$, with higher concentrations in the soil superficial layers. In Spain, Abril et al. (2008) observed a decrease in ${ }^{226} \mathrm{Ra}$ concentration, with increasing soil depth up to $0.9 \mathrm{~m}$, for both control samples and for those that received PG at $25 \mathrm{Mg} \mathrm{ha}^{-1}$.

In order to explain the radionuclide variations along soil depth, Belivermis et al. (2010) found strong positive correlations between natural radionuclide levels and clay or silt content, whereas strong negative correlations for sand were observed. In the present study, increases were observed in the clay amount along soil depths, from $340(0-0.2 \mathrm{~m})$ to $400 \mathrm{~g} \mathrm{~kg}^{-1}(0.6-0.8 \mathrm{~m})$, decreases in sand content, from $506(0-0.2 \mathrm{~m})$ to $443 \mathrm{~g} \mathrm{~kg}^{-1}(0.6-0.8 \mathrm{~m})$. One possible explanation for these results is the existence of correlation between the ${ }^{226} \mathrm{Ra}$ and ${ }^{228} \mathrm{Ra}$ amounts and clay and sand contents along soil depth (Figure 2).

Strong positive correlations between the ${ }^{226} \mathrm{Ra}$ and ${ }^{228} \mathrm{Ra}$ amount and clay content along soil depth were also found in the present study. However, a strong negative correlation between these two radionuclides and sand content was observed. Some authors have described that the natural radioactivity shows increases when particle size decreases and surface area increases. Regarding the grain size, radionuclides are adsorbed onto clay surfaces or fixed within the lattice structure (VandenBygaart \& Protz, 1995; VandenBygaart et al., 1999; Navas et al., 2002; Belivermis et al., 2010).

A reduction in the transfer factors (TF) for ${ }^{226} \mathrm{Ra}$ and ${ }^{228} \mathrm{Ra}$ was noticed for increasing rates of PG (Figure 3 ). In fact, concentrations of ${ }^{226} \mathrm{Ra}$ and ${ }^{228} \mathrm{Ra}$ have not changed in the soil, while concentrations in grains decreased with the increasing PG rates applied. Results of ${ }^{226} \mathrm{Ra}$ and ${ }^{228} \mathrm{Ra}$ in soybean grains were, respectively, 14.3 and $8.5 \%$ lower for the treatment with PG at 12 $\mathrm{Mg} \mathrm{ha}{ }^{-1}$ than for the control treatment without PG. The TFs obtained in the present study were of the same order of magnitude as those found for rice grains produced in Greece, in areas with $\mathrm{PG}(\mathrm{TF}=0.011)$ and without PG ( $\mathrm{TF}=0.016)$ (Papastefanou et al., 2006). The decrease in the concentrations of ${ }^{226} \mathrm{Ra}$ and ${ }^{228} \mathrm{Ra}$ in soybean grains, and consequent reduction of TFs,

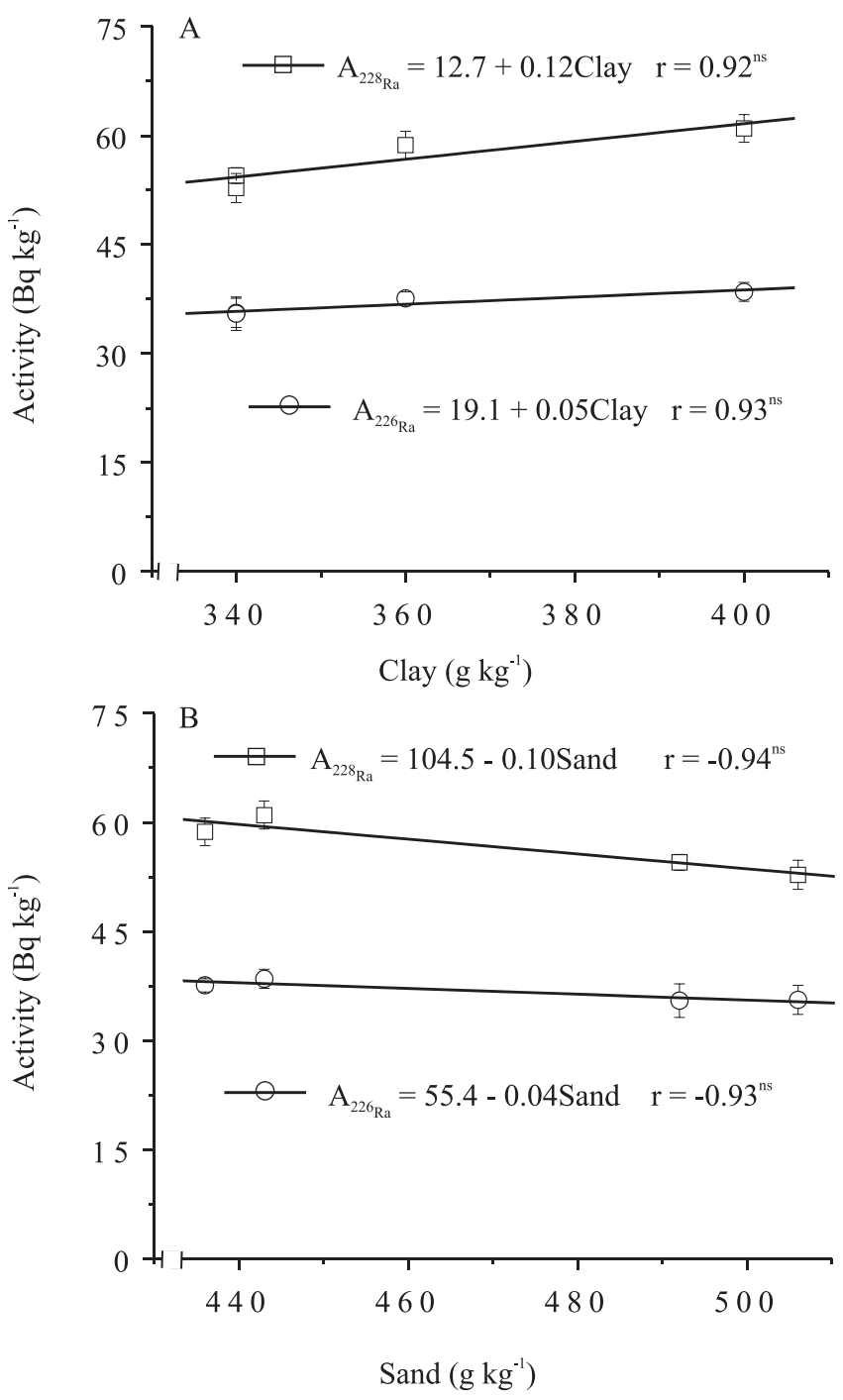

Figure 2. Correlation between clay amount and ${ }^{226} \mathrm{Ra}$ and ${ }^{228} \mathrm{Ra}$ activities along soil depths ( $\left.0-0.8 \mathrm{~m}\right)(\mathrm{A})$, and between sand amount and ${ }^{226} \mathrm{Ra}$ and ${ }^{228} \mathrm{Ra}$ activities along soil depths $(0-0.8 \mathrm{~m})$ (B). Each experimental value represents the activity means for the four phosphogypsum rates applied to the soil (0-12 $\left.\mathrm{Mg} \mathrm{ha}^{-1}\right)$. ${ }^{\mathrm{n}}$ Nonsignificant at 5\% probability. Error bars represent standard deviation $(n=4)$. 
caused by PG application, might be due to increases in $\mathrm{Ca}^{+2}$ content and to the low solubility of $\mathrm{RaSO}_{4}$ in the soil (Papastefanou et al., 2006; Bolca et al., 2007). Increases in $\mathrm{Ca}^{+2}$ concentration in the soil may result in lower Ra transfer from soil to plants due to the chemical similarity between $\mathrm{Ca}$ and $\mathrm{Ra}$, both competing for absorption sites in plants (Bolca et al., 2007).

For soybean produced in other Brazilian regions, Venturini \& Sordi (1999) found activity concentrations lower than $0.43 \mathrm{~Bq} \mathrm{~kg}^{-1}$ for ${ }^{226} \mathrm{Ra}$, and lower than $0.57 \mathrm{~Bq} \mathrm{~kg}^{-1}$ for ${ }^{228} \mathrm{Ra}$, which represents much lower values than those obtained in the present study (Figure 3). Regarding soybean flour, Scheibel
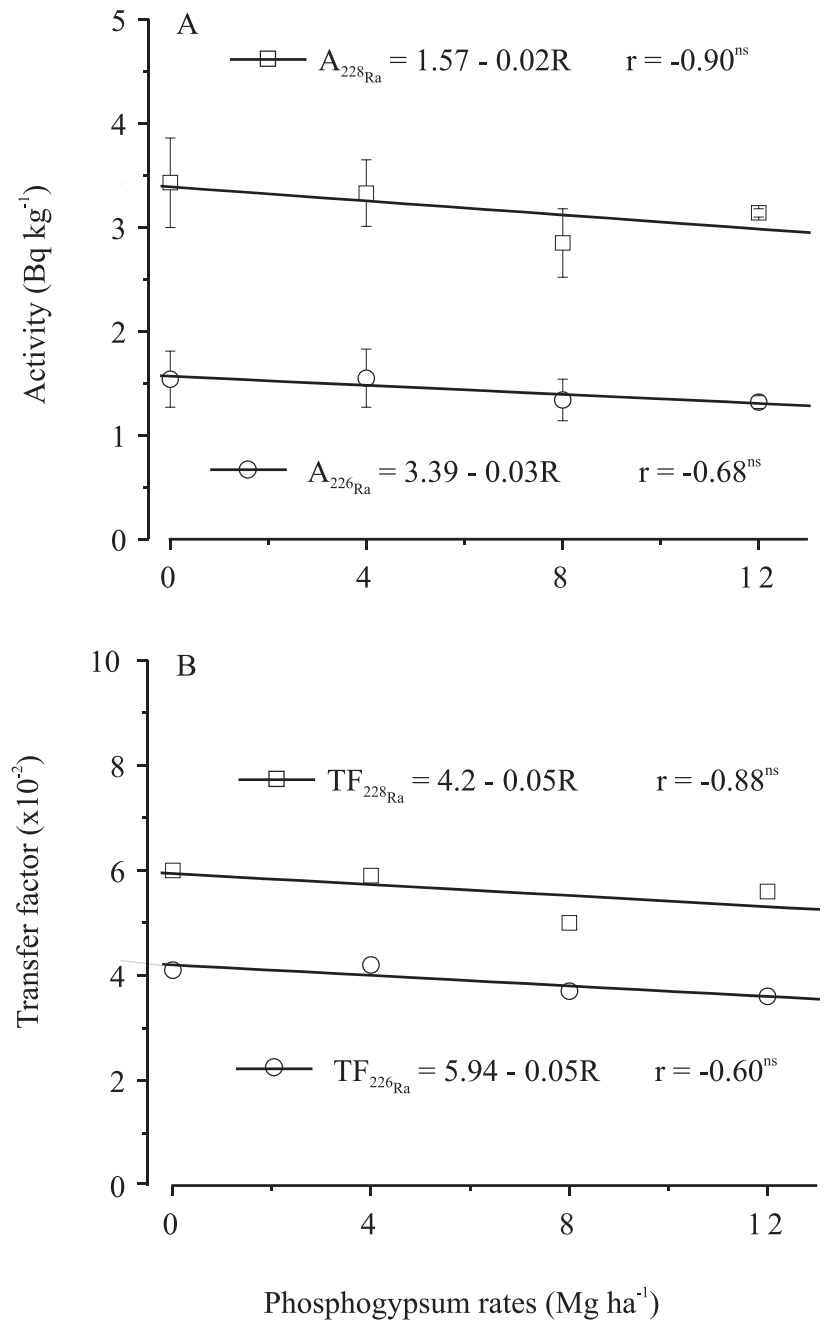

Figure 3. ${ }^{226} \mathrm{Ra}$ and ${ }^{228} \mathrm{Ra}$ activities in soybean grains (A), and soil-plant transfer factor (B) considering the different

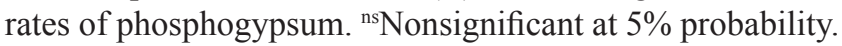
Error bars represent standard deviation $(\mathrm{n}=3)$.
(2006) calculated an average value of $3.5 \mathrm{~Bq} \mathrm{~kg}^{-1}$ for

${ }^{228} \mathrm{Ra}$, similar to those presented here.

Considering an average annual consumption of $1 \mathrm{~kg}$ of soybean per person, the values obtained for ingested activity were compared to the reference values published by United Nations Scientific Committee on the Effects of Atomic Radiation (2000) for water and food (Table 1). The ingestion rate of ${ }^{226} \mathrm{Ra}$ varied according to $P G$ rates, from $1.44 \pm 0.12$ to $3.9 \pm 0.3 \mathrm{mBq}$ per day. Regarding ${ }^{228} \mathrm{Ra}$, it varied from $3.19 \pm 0.26$ to $8.7 \pm 0.7 \mathrm{mBq}$ per day (Figure $4 \mathrm{~A}, \mathrm{~B}$ ). The ingestion of ${ }^{226} \mathrm{Ra}$ would be approximately $19 \%$ (babies), $10 \%$ (children), and 7\% (adults) of typical reference values for water and food ingestion. The ingestion of ${ }^{228} \mathrm{Ra}$ would be approximately 58, 28, and $19 \%$ of the reference values.

Considering the effective dose coefficient for ${ }^{226} \mathrm{Ra}$ and ${ }^{228} \mathrm{Ra}$ from Table 1 , the annual effective dose $\left(D_{e}\right)$ was estimated for humam babies, children and adults (Figure $4 \mathrm{C}, \mathrm{D}$ ). For ${ }^{226} \mathrm{Ra}$ the values were $1.38 \pm 0.12 \mu \mathrm{Sv}$ per year (babies), $1.15 \pm 0.10 \mu \mathrm{Sv}$ per year (children), and $0.40 \pm 0.03 \mu \mathrm{Sv}$ per year (adults), while for ${ }^{228} \mathrm{Ra}$ the values were significantly higher, i.e. $18.2 \pm 1.5 \mu \mathrm{Sv}$ per year (babies), $12.4 \pm 1.0 \mu \mathrm{Sv}$ per year (children), and $2.2 \pm 0.2 \mu \mathrm{Sv}$ per year (adults). Values of $\mathrm{D}_{\mathrm{e}}$ found in the present study were 5.4 (babies), 10.4 (children), and 15.8 (adults) times lower than the ${ }^{226} \mathrm{Ra}$ reference values, and 1.7 (babies), 3.2 (children), and 5.0 (adults) times lower for ${ }^{228} \mathrm{Ra}$ (Table 1). In soybean flour produced in Paraná state, Scheibel (2006) found $\mathrm{D}_{\mathrm{e}}$ values of $1.64 \mu \mathrm{Sv}$ per year (babies), $1.12 \mu \mathrm{Sv}$ per year (children), and $0.20 \mu \mathrm{Sv}$ per year (adults) for ${ }^{228} \mathrm{Ra}$, considering a $0.082 \mathrm{~kg}$ annual consumption of soybean flour.

Table 1. Reference values (United Nations Scientific Committee on the Effects of Atomic Radiation, 2000) for ingested activity (A, mBq per day), effective dose coefficient $\left[\mathrm{e}(\mathrm{g}), \mu \mathrm{Sv} \mathrm{Bq}^{-1}\right]$ and annual effective dose $\left(\mathrm{D}_{\mathrm{e}}, \mu \mathrm{Sv}\right.$ per year $)$ of ${ }^{226} \mathrm{Ra}$ and ${ }^{228} \mathrm{Ra}$ for babies (1-2 years old), children (7-12 years old) and adults (over 17 years old).

\begin{tabular}{lccccccc}
\hline Values & \multicolumn{4}{c}{${ }^{226} \mathrm{Ra}$} & & \multicolumn{3}{c}{${ }^{228} \mathrm{Ra}$} \\
\cline { 2 - 4 } \cline { 7 - 8 } & $\mathrm{A}$ & $\mathrm{e}(\mathrm{g})$ & $\mathrm{D}_{\mathrm{e}}$ & & $\mathrm{A}$ & $\mathrm{e}(\mathrm{g})$ & $\mathrm{D}_{\mathrm{e}}$ \\
\hline Baby & 21 & 0.96 & 7.5 & & 15 & 5.70 & 31.0 \\
Child & 41 & 0.80 & 12.0 & & 27 & 3.90 & 40.0 \\
Adult & 60 & 0.28 & 6.3 & & 41 & 0.69 & 11.0 \\
\hline
\end{tabular}



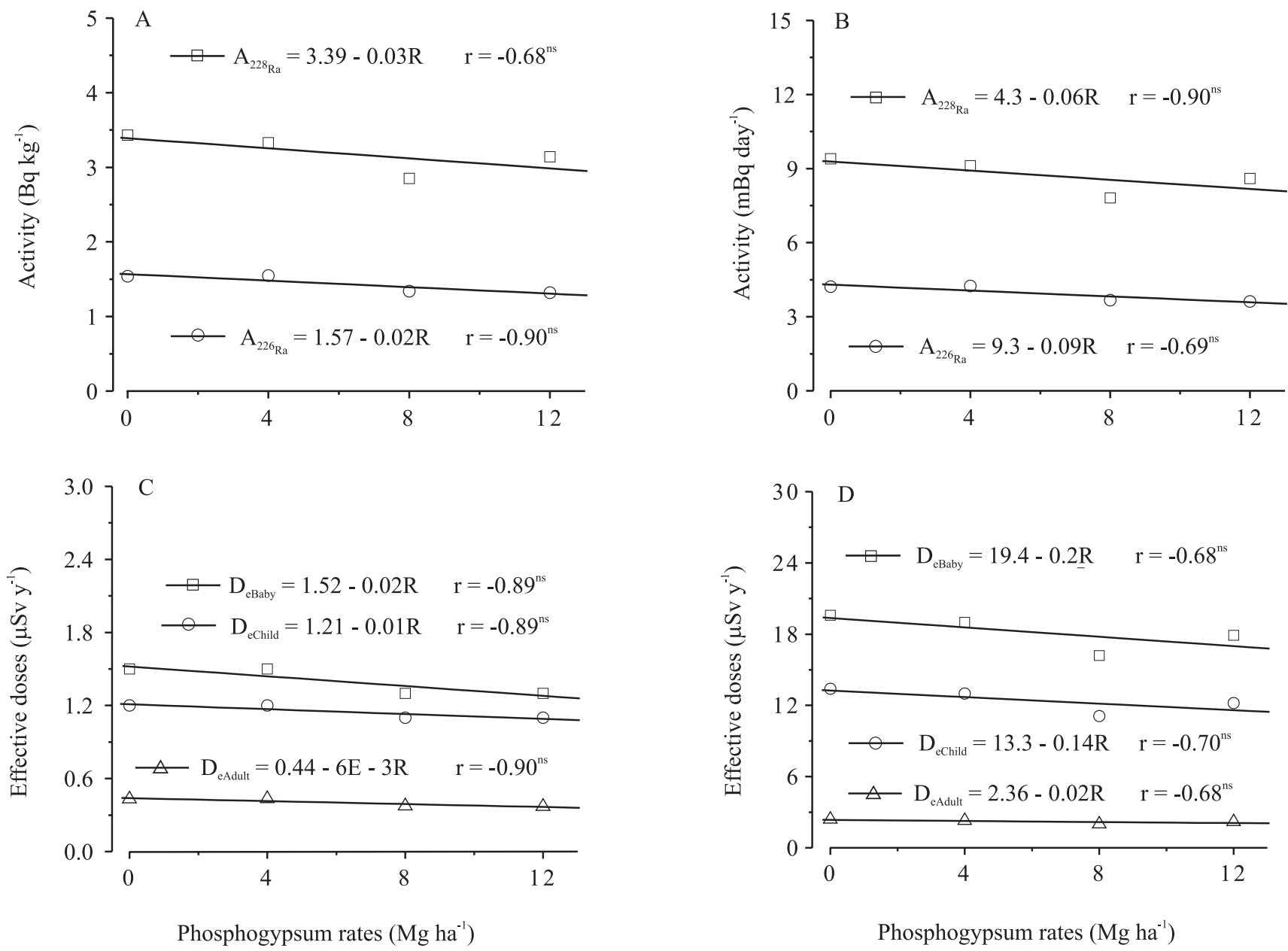

Figure 4. Ingested activity of ${ }^{226} \mathrm{Ra}$ and ${ }^{228} \mathrm{Ra}$ according to phosphogypsum rates applied to the soil: A, ingested activity per year; $\mathrm{B}$, ingested activity per day; $\mathrm{C}$, ingestion effective dose of ${ }^{226} \mathrm{Ra}$ for babies, children and adults; $\mathrm{D}$, ingestion effective dose of ${ }^{228} \mathrm{Ra}$ for babies, children and adults. ${ }^{\mathrm{n}}$ Nonsignificant at $5 \%$ probability.

\section{Conclusions}

1. Surface application of phosphogypsum up to $12 \mathrm{Mg} \mathrm{ha}^{-1}$ in an Oxisol under no-till system does not increase the concentrations of ${ }^{226} \mathrm{Ra}$ and ${ }^{228} \mathrm{Ra}$ in soil.

2. The concentrations of both radionuclides are higher in the subsoil layers compared to the topsoil.

3. Increasing phosphogypsum rates result in lower soil-plant transfer factor for ${ }^{226} \mathrm{Ra}$ and ${ }^{228} \mathrm{Ra}$.

4. Surface application of phosphogypsum for soybean production under no-till system is a safe practice regarding possible radiological damage to human health, considering the conditions of this study.

\section{Acknowledgments}

To Conselho Nacional de Desenvolvimento Científico e Tecnológico, for grants; and to Fundação Araucária/Fundo Paraná/SETI/Governo do Paraná, for financial support.

\section{References}

ABRIL, J.M.; GARCÍA-TENORIO, R.; ENAMORADO, S.M.; HURTADO, M.D.; ANDREU, L.; DELGADO, A. The cumulative effect of three decades of phosphogypsum amendments in reclaimed marsh soils from SW Spain: ${ }^{226} \mathrm{Ra},{ }^{238} \mathrm{U}$ and $\mathrm{Cd}$ contents in soils and tomato fruit. Science of the Total Environment, v.403, p.80-88, 2008 . 
ABRIL, J.M.; GARCÍA-TENORIO, R.; PERIÁÑEZ, R.; ENAMORADO, S.M.; ANDREU, L.; DELGADO, A. Occupational dosimetric assessment (inhalation pathway) from the application of phosphogypsum in agriculture in South West Spain. Journal of Environmental Radioactivity, v.100, p.29-34, 2009.

ALBUQUerQue, G. de A.S.C. de. A produção de fosfato no Brasil: uma apreciação histórica das condicionantes envolvidas. Rio de Janeiro: Centro de Tecnologia Mineral, 1996, 129p. (Séries Estudos e Documentos, 31).

BACCHI, M.A. Quantificação de terra em carregamentos de cana-de-açúcar pela determinação de radionuclídeos de ocorrência natural. 1996. 130p. Tese (Doutorado) - Universidade de São Paulo, Piracicaba.

BACCHI, M.A.; FERNANDES, E.A.N.; FRANÇA, E.J. de. A semiempirical approach for the determination of $\mathrm{HPGe}$ detector photopeak efficiency aiming at $\mathrm{k}_{0}$-INAA. Journal of Radioanalytical and Nuclear Chemistry, v.245, p.209-215, 2000 .

BEDDOW, H.; BLACK, S.; READ, D. Naturally occurring radioactive material (NORM) from a former phosphoric acid processing plant. Journal of Environmental Radioactivity, v.86, p.289-312, 2006.

BELIVERMIS, M.; KILIÇ, Ö.; ÇOTUK, Y.; TOPCUO־GLU, S. The effects of physicochemical properties on gamma emitting natural radionuclide levels in the soil profile of Istanbul. Environmental Monitoring and Assessment, v.163, p.15-26, 2010.

BOLCA, M.; SAÇ, M.M.; ÇOKUYSAL, B.; KARALI, T.; EKDAL, E. Radioactivity in soils and various foodstuffs from the Geiz River Basin of Turkey. Radiation Measurements, v.42, p.263-270, 2007.

BURNETT, W.C.; ELZERMAN, A.W. Nuclide migration and the environmental radiochemistry of Florida phosphogypsum. Journal of Environmental Radioactivity, v.54, p.27-51, 2001.

CAIRES, E.F.; ALLEONI, L.R.F.; CAMBRI, M.A.; BARTH, G. Surface application of lime for crop grain production under a no-till system. Agronomy Journal, v.97, p.791-798, 2005.

CAIRES, E.F.; BLUM, J.; BARTH, G.; GARBUIO, F.J.; KUSMAN, M.T. Alterações químicas do solo e resposta da soja ao calcário e gesso aplicados na implantação do sistema plantio direto. Revista Brasileira de Ciência do Solo, v.27, p.275-286, 2003.

CAIRES, E.F.; CHUEIRI, W.A.; MADRUGA, E.F.; FIGUEIREDO, A. Alterações de características químicas do solo e resposta da soja ao calcário e gesso aplicados na superfície em sistema de cultivo sem preparo do solo. Revista Brasileira de Ciência do Solo, v.22, p.27-34, 1998.

CANUT, M. Estudo da viabilidade da substituição do gesso pelo rejeito fosfogesso em material de construção. 2006. 110p. Dissertação (Mestrado) - Universidade Federal de Minas Gerais, Belo Horizonte.

CARVALHO, M.C.S.; RAIJ, B. VAN. Calcium sulphate, phosphogypsum and calcium carbonate in the amelioration of acid subsoils for root growth. Plant and Soil, v.192, p.37-48, 1997.

CHOPPIN, G.R.; RYDBERG, J. Nuclear chemistry: theory and application. New York: Pergamon Press, 1980. 667p.
DIAS, N.M.P.; CAIRES, E.F.; PIRES, L.F.; BACCHI, M.A.; FERNANDES, E.A.N. Radiological impact of phosphogypsum application in agriculture. AIP Conference Proceedings, v.1265, p.447-448, 2010.

ERNANI, P.R.; RIBEIRO, M.F.S.; BAYER, C. Chemical modifications caused by liming below the limed layer in a predominantly variable charge acid soil. Communications in Soil Science and Plant Analysis, v.35, p.889-901, 2004.

ETTENHUBER, E.; LEHMANN, R. The collective dose equivalent due to the naturally occurring radionuclides in building materials in the German Democratic Republic. Part 1: external exposure. Health Physics, v.50, p.49-56, 1986.

HULL, C.D.; BURNETT, W.C. Radiochemistry of Florida phosphogypsum. Journal of Environmental Radioactivity, v.32, p.213-238, 1996.

JACOMINO, V.M.F.; OLIVEIRA, K.A.P. de; TADDEI, M.H.T.; SIQUEIRA, M.C.; CARNEIRO, M.E.D.P.; NASCIMENTO, M.R.L.; SILVA, D.F.; MELLO, J.W.V. Radionuclides and heavy metal contents in phosphogypsum samples in comparison to Cerrado soils. Revista Brasileira de Ciência do Solo, v.33, p.1481-1488, 2009.

MALANCA, A.; PESSINA, V.; DALLARA, G. Assessment of the natural radioactivity in the Brazilian state of Rio Grande do Norte. Health Physics, v.65, p.298-302, 1993.

MAZZILLI, B.; PALMIRO, V.; SAUEIA, C.; NISTI, M.B. Radiochemical characterization of Brazilian phosphogypsum. Journal of Environmental Radioactivity, v.49, p.113-122, 2000.

NAVAS, A.; SOTOB, J.; MACHÍN, J. ${ }^{238} \mathrm{U},{ }^{226} \mathrm{Ra},{ }^{210} \mathrm{~Pb},{ }^{232} \mathrm{Th}$ and ${ }^{40} \mathrm{~K}$ activities in soil profiles of the Flysch sector (Central Spanish Pyrenees). Applied Radiation and Isotopes, v.57, p.579-589, 2002.

PAPASTEFANOU, C.; STOULOS, S.; IOANNIDOU, A.; MANOLOPOULOU, M. The application of phosphogypsum in agriculture and the radiological impact. Journal of Environmental Radioactivity, v.89, p.188-198, 2006.

PARREIRA, P.S.; APPOLONI, C.R.; NASCIMENTO FILHO, V.F. Qualitative evaluation of the soil radioactivity enhancement due to the use of phosphogypsum. Journal of Nuclear Agriculture and Biology, v.30, p.1-11, 2001.

RUTHERFORD, P.M.; DUDAS, M.J.; SAMEK, R.A. Environmental impacts of phosphogypsum. The Science of the Total Environment, v.149, p.1-38, 1994.

SANTOS, A.J.G.; MAZZILLI, B.P.; FÁVARO, D.I.T.; SILVA, P.S.C. Partitioning of radionuclides and trace elements in phosphogypsum and its source materials based on sequential extraction methods. Journal of Environmental Radioactivity, v.87, p.52-61, 2006.

SAUEIA, C.H.; MAZZILLI, B.P.; FÁVARO, D.I.T. Natural radioactivity in phosphogypsum and phosphate fertilizers in Brazil. Journal of Radioanalytical and Nuclear Chemistry, v.264, p.445-448, 2005.

SCHEIBEL, V. Determinação das doses efetivas por ingestão de farinhas de cereais através da espectrometria de raios gama. 2006. 131p. Tese (Doutorado) - Universidade Estadual de Londrina, Londrina. 
SHAINBERG, I.; SUMNER, M.E.; MILLER, W.P.; FARINA, M.P.W.; PAVAN, M.A.; FEY, M.V. Use of gypsum on soils: a review. Advances in Soil Sciences, v.9, p.1-111, 1989.

SILVA, N.C. da. Radionuclídeos naturais e elementos tóxicos em pilhas de fosfogesso no Brasil: caracterização e lixiviação. 2001. 119p. Tese (Doutorado) - Universidade de São Paulo, Piracicaba.

SILVA, N.C. da; FERNANDES, E.A.N.; CIPRIANI, M.; TADDEI, M.H.T. The natural radioactivity of Brazilian phosphogypsum. Journal of Radioanalytical and Nuclear Chemistry, v.249, p.251-255, 2001.

SAS INSTITUTE. SAS/STA guide for personal computers. Cary: SAS Institute, 1985. 378p.

UNITED NATIONS SCIENTIFIC COMMITTEE ON THE EFECTS OF ATOMIC RADIATION. Sources and effects of ionizing radiation. Volume I. Sources. New York: UNSCEAR, 2000.

UNITED STATESENVIRONMENTALPROTECTIONAGENCY. Code of Federal Regulations: 40CFR61.202 and 40CFR61.204: title 40: protection of environment. [S.1.]: EPA, 1998.

VANDENBYGAART, A.J.; PROTZ, R. Gamma radioactivity on chronosequence, Pinery Provincial Park, Ontario. Canadian Journal of Soil Science, v.75, p.73-84, 1995.

VANDENBYGAART, A.J.; PROTZ, R.; MCCABE, D.C. Distribution of natural radionuclides and Cs-137 in soils of southwestern Ontario. Canadian Journal of Soil Science, v.79, 161-171, 1999.

VENTURINI, L.; SORDI, G.A.A. Radioactivity in and committed effective dose from some Brazilian foodstuffs. Health Physics, v.76, p.311-313, 1999.

$\overline{\text { Received on October 12, } 2010 \text { and accepted on November 29, } 2010}$ 